\title{
Pengaruh Iklim Komunikasi Organisasi Terhadap Efektivitas Komunikasi Interpersonal Dan Kepuasan Kerja (Studi Eksplanatif di Dinas Kebudayaan, Pariwisata, Pemuda dan Olah Raga Kabupaten Gunung Mas Kalimantan Tengah)
}

\author{
Sri Wahyunie ${ }^{1}$; Sanggar Kanto ${ }^{2}$; Rachmat Kriyantono ${ }^{3}$ \\ ${ }^{123}$ Program Magister IImu Komunikasi, Fakultas IImu Sosial dan Politik, Universitas Brawijaya, Jl. Veteran Malang 65145.
}

\begin{abstract}
Abstrak
Penelitian ini bertujuan untuk mengetahui pengaruh iklim komunikasi organisasi terhadap efektivitas komunikasi interpersonal dan kepuasan kerja di Dinas Kebudayaan, Pariwisata, Pemuda dan Olah Raga Kabupaten Gunung Mas Kalimantan Tengah. Penelitian dilakukan di kantor Dinas Kebudayaan, Pariwisata, Pemuda dan Olah Raga Kabupaten Gunung Mas Kalimantan Tengah pada bulan September 2014 untuk pengambilan data. Metode yang digunakan dalam penelitian ini adalah penelitian kuantitatif, dengan melibatkan 33 responden yang dipilih sesuai populasi yang ada. Alat pengumpul data yang digunakan adalah kuesioner. Analisis data dalam penelitian ini menggunakan uji analisis jalur (Path Analysis),dimana analisis jalur ini menguji apakah terdapat pengaruh langsung atau tidak langsung iklim komunikasi organisasi terhadap kepuasan kerja.

Hasil penelitian menunjukkan nilai iklim komunikasi organisasi memperoleh nilai gabungan 3,53. Nilai efektivitas komunikasi interpersonal memperoleh nilai gabungan 3,87. Nilai kepuasan kerja memperoleh nilai gabungan 3,96. Hasil penelitian menunjukkan tingkat kepuasan kerja pegawai di Dinas Kebudayaan, Pariwisata, Pemuda dan Olah Raga berada pada tingkat cukup baik. Iklim komunikasi secara langsung memiliki pengaruh yang positif dan signifikan terhadap efektivitas komunikasi interpersonal dengan taraf signifikansi sebesar 0,026. Iklim komunikasi secara langsung memiliki pengaruh yang positif dan signifikan terhadap kepuasan kerja dengan taraf signifikansi sebesar 0,036. Efektivitas komunikasi interpersonal secara langsung memiliki pengaruh yang positif dan signifikan terhadap kepuasan kerja dengan taraf signifikansi sebesar 0,001 . Iklim komunikasi organisasi juga secara tidak langsung memiliki pengaruh terhadap kepuasan kerja dengan melalui efektivitas komunikasi interpersonal sebagai mediasinya dengan taraf signifikansi sebesar 0,171 atau $17,1 \%$. Secara simultan terdapat Pengaruh iklim komunikasi organisasi dan efektivitas komunikasi interpersonal terhadap kepuasan kerja secara gabungan adalah $37,6 \%$ sedangkan $62,4 \%$ dipengaruhi oleh faktor lain.
\end{abstract}

Kata Kunci: iklim komunikasi organisasi, efektivitas komunikasi interpersonal, kepuasan kerja

\section{Abstract}

This study aims to determine the effect of organizational communication climate on the effectiveness of interpersonal communication and job satisfaction in the Department of Culture, Tourism, Youth and Sport in Gunung Mas district of Central Kalimantan. The study was conducted at the office of the Department of Culture, Tourism, Youth and Sports in Gunung Mas district of Central Kalimantan in September 2014 for data retrieval. The method used in this study was a quantitative study, involving 33 respondents were selected according to population. Data collection tool used was a questionnaire. The questionnaire used in this study was enclosed questionnaire using Likert scale. Data analysis in this study using path analysis test (Path Analysis), in which path analysis was to test whether there was a direct or indirect effect of organizational communication climate on job satisfaction.

The result showed the value of organizational communication climate obtained a combined value of 3.53. The value of the effectiveness of interpersonal communication obtained a combined value of 3.87. The value of job satisfaction obtained a combined value of 3.96. The result showed the level of job satisfaction of employees in the Department of Culture, Tourism, Youth and Sport in Gunung Mas district of Central Kalimantan is at a good enough level. The climate communication directly has a positive and significant impact on the effectiveness of interpersonal communication with a significant level of 0.036 . The Climate communication directly has a positive and significant effect on job satisfaction with a significant level of 0.001 . The Organizational communication climate also indirectly has an effect on job satisfaction through interpersonal communication effectiveness as mediation with a significant level of 0.171 or $17 \%$. Simultaneously, there is the effect of organizational communication climate on the effectiveness of interpersonal communication and job satisfaction is combined of $37.6 \%$, while of $62.4 \%$ is influenced by other factors.

Key Word: organizational communication climate, effectiveness of interpersonal communication, job satisfaction 


\section{PENDAHULUAN}

Komunikasi merupakan aktivitas yang paling mendasar dari manusia. Dengan berkomunikasi, manusia dapat saling berhubungan antara satu dengan yang lainnya baik dalam kehidupan pribadi maupun dalam masyarakat. Pentingnya komunikasi bagi manusia tidaklah dapat dipungkiri, begitu juga halnya dengan suatu organisasi. Dengan adanya komunikasi yang baik, maka organisasi akan dapat berjalan dengan lancar dan berhasil, demikian juga sebaliknya. Kurangnya komunikasi dalam organisasi akan mengakibatkan macetnya kinerja organisasi [1].

Komunikasi juga ditujukan untuk menumbuhkan hubungan sosial yang baik. Manusia adalah makhluk sosial yang tidak tahan hidup menyendiri. Manusia ingin berhubungan dengan orang lain secara positif. Abraham Maslow menyebutnya dengan "kebutuhan cinta" [2]. Tingkah laku komunikasi mengarahkan pada perkembangan iklim organisasi. Iklim organisasi dipengaruhi oleh bermacam-macam cara anggota bertingkah laku dan berkomunikasi. Iklim komunikasi yang penuh dengan persaudaraan mendorong anggota organisasi untuk berkomunikasi secara terbuka, rileks dan ramah tamah dengan anggota lainnya. Sedangkan iklim yang negatif menjadikan anggota tidak berani berkomunikasi secara terbuka dan penuh dengan persaudaraan [1]. Kondisi yang demikian, apabila tidak diperhatikan secara serius oleh seorang pemimpin akan berpengaruh secara langsung terhadap iklim organisasi.

Redding [3] mengatakan iklim komunikasi organisasi merupakan fungsi kegiatan yang terdapat dalam organisasi untuk menunjukkan kepada anggota organisasi bahwa organisasi tersebut mempercayai mereka dan memberi mereka kebebasan dalam mengambil resiko mendorong mereka dan memberi mereka tanggung jawab dalam mengerjakan tugastugas mereka dan menyediakan informasi yang terbuka dan cukup tentang organisasi mendengarkan dengan penuh perhatian serta memperoleh informasi yang dapat dipercaya dan terus terang dari anggota organisasi secara aktif memberi penyuluhan kepada para anggota organisasi sehingga mereka dapat melihat bahwa keterlibatan mereka penting bagi keputusan-keputusan dalam organisasi dan menaruh perhatian pada pekerjaan yang bermutu tinggi dan memberi tantangan.

Dalam suatu organisasi, iklim komunikasi sangat erat kaitannya dengan kepuasan kerja para karyawan dan prestasi organisasinya. Bahkan [4] mengatakan bahwa iklim tersebut dipandang sebagai suatu variabel kunci yang mempengaruhi kepuasan kerja dan produktifitas karyawan dalam usaha menunjang gerak organisasi yang selalu berkembang. Dennis, Richetto dan Wieman [5] juga menyatakan bahwa ada hubungan yang positif antara iklim yang tercipta dengan kepuasan dan efektifitas organisasi.
Menurut [6] terciptanya iklim komunikasi yang sehat setidaknya menyangkut tiga komponen pokok yaitu kuantitas informasi, kualitas isi pesan dan sifat saluran informasi yang tersedia. Kuantitas informasi menyangkut jumlah informasi yang diperoleh bawahan yang akan menghasilkan suatu pengetahuan, pemahaman dan kepercayaan terhadap organisasi. Sedangkan sumber kualitas informasi dapat ditemukan dari level atas sampai level bawah suatu organisasi. Kuantitas dan kualitas informasi tersebut tidak akan berarti tanpa tersedianya saluran informasi yang berupa saluran formal dan informal.

Iklim Komunikasi organisasi merupakan suatu syarat bagi peningkatan produktivitas dan prestasi kerja organisasi, sehingga secara tidak langsung akan berhubungan dengan pencapaian tujuan organisasi. Hal ini terjadi karena apabila karyawan memiliki komunikasi yang yang efektif dalam organisasi maka akan muncul loyalitas kepada organisasi dan menjalin hubungan aktif dan saling mendukung dalam mencapai tujuan organisasi yang bersangkutan. Selain itu, komunikasi yang efektif menyebabkan mereka akan bekerja, bersikap dan berperilaku baik dan keras untuk organisasi [7].

Goldhaber dalam [8]. mengutarakan ada 5 (lima) dimensi yang mempengaruhi iklim komunikasi organisasi. Kelima dimensi tersebut yaitu: 1) Kepercayaan; 2) Pembuat keputusan bersama; 3) Dukungan; 4) Keterbukaan; dan 5) Perhatian atas tujuan kinerja tinggi.

Komunikasi interpersonal yang mumpuni mampu berinteraksi dalam cara yang efektif dan tepat dengan situasi. Artinya, kita harus menyesuaikan gaya komunikasi untuk mencapai tujuan, situasi, dan orangorang yang spesifik. Efektivitas dan kesesuaian adalah syarat untuk menerima dan menghargai perbedaan kebudayaan. Panduan untuk menerapkan cara ini adalah dengan mengembangkan beragam kemampuan berkomunikasi, melatih kepekaan sensitivitas dalam berkomunikasi, melihat perbedaan dalam dua perspektif, mengatur apa yang akan dikatakan, dan berkomitmen terhadap etika dalam komunikasi interpersonal [9].

[10] menyatakan ada lima kualitas umum yang dipertimbangkan dalam efektivitas komunikasi interpersonal yaitu: 1) Keterbukaan; 2) Empati; 3) Sikap Mendukung; 4) Sikap Positif; dan 5) Kesetraan.

Untuk mengelola dan mengendalikan berbagai fungsi subsistem dalam organisasi agar tetap konsisten dengan tujuan organisasi dibutuhkan seorang pemimpin karena pemimpin merupakan bagian penting dalam peningkatan kinerja para pekerja (Bass, 1994 dalam [11]). Disamping itu kemampuan pemimpin dalam menggerakan dan memberdayakan karyawannya akan berpengaruh terhadap kinerja karyawan. Perubahan lingkungan dan tehnologi yang cepat meningkatkan kompleksitas tantangan yang dihadapi oleh organisasi, hal ini memunculkan kebutuhan organisasi terhadap 
pemimpin yang dapat mengarahkan dan mengembangkan usaha-usaha bawahan dengan kekuasaan yang dimiliki untuk mencapai tujuan organisasi dalam membangun organisasi menuju high performance (Harvey dan Brown, 1996, dalam [8]). Perilaku pemimpin mempunyai dampak signifikan terhadap sikap, perilaku dan kinerja pegawai. Efektivitas pemimpin dipengaruhi oleh karakteristik bawahannya dan terkait dengan proses komunikasi yang terjadi antara pemimpin dan bawahan. Ketidak berhasilan pemimpin dikarenakan pemimpin tidak mampu menggerakan dan memuaskan karyawan pada suatu pekerjaan dan lingkungan tertentu. Tugas pimpinan adalah mendorong bawahan supaya memiliki kompetensi dan kesempatan berkembang dalam mengantisipasi setiap tantangan dan peluang dalam bekerja [12].

Tugas manajemen sumber daya manusia berkisar pada upaya mengelola unsur manusia dengan potensi yang dimiliki sehingga dapat diperoleh sumber daya manusia yang puas (satisfied) dan memuaskan (satisfactory) bagi organisasi [13]. Salah satu tujuan bekerja adalah memperoleh kepuasan kerja. Kepuasan kerja berkaitan erat antara sikap pegawai terhadap berbagai faktor dalam pekerjaan, antara lain: situasi kerja, pengaruh sosial dalam kerja, imbalan dan kepemimpinan serta faktor lain. (Lodge \& Derek, dalam [14]). Orang akan merasa puas apabila tidak ada perbedaan (discrepancy) antara yang diinginkan dengan persepsinya atas kenyataan. Meskipun terdapat perbedaan akan tetapi kalau perbedaan tersebut positif maka orang atau pegawai akan merasa puas, demikian juga sebaliknya. Pegawai akan merasa puas bila mendapatkan sesuatu yang dibutuhkan. Makin besar kebutuhannya yang terpenuhi akan semakin puas, begitu sebaliknya.

Pembahasan tentang kepuasan kerja karyawan tidak bisa dilepaskan dari kenyataan bahwa kepuasan kerja karyawan dapat dicapai apabila semua harapannya dapat dipenuhi dalam melaksanakan tugas pekerjaannya. Kepuasan kerja merupakan refleksi dari perasaan dan sikap individu terhadap pekerjaannya, yang merupakan interaksi antara yang bersangkutan dengan lingkungan kerjanya. [7] menyatakan ada lima faktor yang mempengaruhi kepuasan kerja yaitu: pengasilan, rekan kerja, kesempatan berkembang, pekerjaan itu sendiri, serta supervisor.

Lawler dalam [15] mengatakan ukuran kepuasan sangat didasarkan atas kenyataan yang dihadapi dan diterima sebagai kompensasi usaha dan tenaga yang diberikan. Kepuasan kerja tergantung dari kesesuaian atau keseimbangan (equity) antara yang diharapkan dengan kenyataan. Indikasi kepuasan kerja biasanya dikaitkan dengan tingkat absensi, tingkat perputaran tenaga kerja, disiplin kerja, loyalitas dan konflik di lingkungan kerja.

Pada dasarnya banyak para ahli mendefinisikan kepuasan kerja namun demikian, secara umum tidak banyak perbedaan yang di tekankan tentang kepuasan kerja. Umumnya kepuasan didefinisikan sebagai sikap umum saeseorang individu terhadap pekerjaannya. Sementara menurut Celluci dan DeVries dalam [16] faktor-faktor yang mendorong kepuasan kerja adalah: 1) Kepuasan terhadap gaji; 2) Kepuasan terhadap promosi; 3) Kepuasan terhadap rekan kerja; 4) Kepuasan kerja terhadap supervise; dan 5) Kepuasan terhadap pekerjaan itu sendiri.

Penelitian [17] menyatakan bahwa insentif, motivasi kerja, gaya kepemimpinan dan budaya organisasi baik secara parsial atau simultan berpengaruh terhadap kepuasan kerja personil polri pada Satuan Kerja Biro Operasi Polda Aceh. Berikutnya penelitian [18] menyatakan motivasi dan budaya organisasi berpengaruh positif terhadap kepuasan kerja karyawan PT. Pei Hai International Wiratama Indonesia. Selanjutnya [19] hasil penelitiannya di British International School menyatakan hubungan konpensasi yang diterima karyawan dan iklim organisasi secara bersama-sama menunjukkan hubungan yang sangat kuat dan positif terhadap kepuasan kerja. Namun hubungan konpensasi terhadap kepuasan kerja lebih besar dibandingkan hubungan iklim organisasi terhadap kepuasan kerja. Hal ini menunjukkan bahwa menciptakan konpensasi dan proses balas jasa yang baik terhadap karyawan akan lebih mendorong kepuasan kerja karyawan dibandingkan dengan mepnciptakan iklim organisasi yang baik.

Alasan peneliti memilih Dinas Kebudayaan, Pariwisata, Pemuda dan Olah Raga Kabupaten Gunung Mas Kalimantan Tengah sebagai objek penelitian yaitu karena kurang efektifnya komunikasi yang terjalin baik sesama karyawan (komunikasi horizontal) maupun atasan dan bawahan ataupun sebaliknya (komunikasi vertikal) sehingga mengakibatkan semangat kerja karyawan kurang meningkat.

Dinas Kebudayaan Pariwisata Pemuda dan Olah Raga yang beralamatkan di jalan Pangeran Diponegoro dengan jumlah pegawai 33 orang dengan berbagai jabatan dan bidang yang berbeda, secara umum iklim komunikasi juga sangat berbeda berdasarkan bidangnya dan sangat mempengaruhi pola komunikasi antar pegawai, seperti bidang kebudayaan dengan bidang pemuda dan olah raga. Sebagai organisasi atau lembaga yang mempunyai misi terhadap budaya, pariwisata dan prestasi-prestasi bidang olah raga saat ini dihadapkan pada beberapa permasalahan yang terkait dengan SDM khususnya dalam hal komitmen keorganisasian pegawainya. Dari beberapa studi sebelumnya, iklim komunikasi organisasi memiliki pengaruh signifikan terhadap kepuasan kerja. Apabila iklim komunikasi organisasi baik maka kepuasan kerja para pegawainya juga akan baik. Begitu juga dengan efektivitas komunikasi interpersonal, apabila efektivitas komunikasi 
interpersonal diantara para pegawai baik, maka kepuasan kerja juga akan tinggi.

Berdasarkan pengalaman dan interaksi terhadap rekan kerja peneliti dalam berorganisasi di Dinas Kebudayaan Pariwisata Pemuda dan Olah Raga meskipun setiap anggota organisasi berkomunikasi dari waktu ke waktu satu sama lain, namun tetap ada kesenjangan antara ekspektasi atasan dan kinerja karyawan dalam mengimplementasikan tugas-tugas yang diberikan kepada mereka. Kurang efektifnya komunikasi yang terjalin baik sesama karyawan (komunikasi horizontal) maupun atasan dan bawahan ataupun sebaliknya (komunikasi vertikal). Contohnya masih ada kebijakan yang telah ditetapkan namun belum dilaksanakan dengan baik. Hal tersebut biasanya berdampak kepada kepuasan kerja dari karyawan atau karyawan kurang bersungguh-sungguh dalam menjalankan kewajiban atau tugas yang menjadi tanggung jawab karyawan.

Melalui hasil wawancara pendahuluan yang telah dilakukan dengan Kepala Dinas Kebudayaan, Pariwisata, Pemuda dan Olah Raga Kabupaten Gunung Mas Kalimantan Tengah, peneliti memperoleh informasi mengenai adanya iklim komunikasi yang baik dalam sebuah organisasi dengan prinsip yang terdapat dalam Teori Komunikasi. Kepala Dinas menjelaskan, bahwa iklim komunikasi yang baik dalam sebuah organisasi khususnya Dinas Kebudayaan, Pariwisata, Pemuda dan Olah Raga Kabupaten Gunung Mas Kalimantan Tengah adalah, dukungan dari setiap pegawai dalam organisasi. Selain itu iklim komunikasi organisasi yang baik perlu diciptakan oleh semua anggota dari organisasi tersebut, sehingga tercipta iklim yang baik dalam bekerja, serta nantinya berhubungan erat dengan kinerja karyawan.

Temuan tersebut dirasa penting bagi peneliti untuk ditindaklanjuti. Peneliti merasa bahwa penting untuk mengetahui apakah Teori komunikasi telah diterapkan dalam organisasi tersebut. Mengingat bahwa ikloim komuniksi tidak hanya merupakan kegiatan praktis, tetapi juga ilmu pengetahuan yang bersifat teoritis. Peneliti berpandangan bahwa perlu adanya upaya penelitian untuk melihat apakah 5 prinsip iklim komunikasi dalam Teori Komunikasi yang menjadi teori atau pedoman iklim komunikasi organisasi yang efektif benar-benar telah mencerminkan karakteristik di kalangan organisasi. Komponen lain selain gaji dan fasilitas yang mempengaruhi kepuasan kerja di Dinas Kebudayaan Pariwisata Pemuda dan Olah Raga biasanya terdiri dari penghargaan yang diberikan kepada karyawan, komunikasi, hubungan dengan atasan dan teman kerja, kondisi pekerjaan, keamanan dan lain lain. Kepuasan kerja bersifat dinamis, yang berarti berkembang terus tergantung harapan yang ada di lingkungan kerja. Maka dari setiap indikator yang mempengaruhi iklim komunikasi organisasi untuk mencapai efektivitas komunikasi organisasi dan kepuasan kerja karyawan diharapkan dengan ada penelitian ini dapat diketahui indikator mana yang yang berpengaruh terhadap efektivitas komunikasi interpersonal dan kepuasan kerja Dinas Kebudayaan Pariwisata Pemuda dan Olah Raga.

Iklim komunikasi organisasi yang ada di Dinas Kebudayaan Pariwisata Pemuda dan Olah Raga turut mempengaruhi kondisi efektivitas komunikasi interpersonal dan kepusan kerja pegawainya. Apabila iklim komunikasi organisasinya baik maka kepuasan kerja pegawainya juga akan tinggi. Begitu juga dengan efektivitas komunikasi interpersonal apabila komunikasi interpersonal pegawai tinggi maka kepuasan kerja juga akan tinggi. Kedua hal tersebut juga bermakna sebaliknya apabila kedua faktor tersebut buruk atau rendah maka akan rendah juga kepuasan kerja yang ada di Iklim komunikasi organisasi yang ada di Dinas Kebudayaan Pariwisata Pemuda dan Olah Raga.

Penelitian ini bertujuan untuk mengetahui pengaruh iklim komunikasi organisasi terhadap efektivitas komunikasi interpersonal dan kepuasan kerja pegawai di Dinas Kebudayaan Pariwisata Pemuda dan Olah Raga Kabupaten Gunung Mas Kalimantan Tengah.

\section{METODE PENELITIAN}

Metode penelitian yang digunakan adalah metode penelitian survey dengan memberikan angket/kuesioner kepada responden (Pegawai) yang akan menjawab pernyataan-pernyataan tentang pengaruh iklim komunikasi organisasi, efektivitas komunikasi interpersonal dan kepuasan kerja pada Pegawai Dinas Budaya, Pariwisata, Pemuda dan Olah Raga di Kabupaten Gunung Mas Kalimantan Tengah.

Metode survei dipilih karena peneliti menggunakan kuesioner dan wawancara sebagai alat pengumpulan data. Seperti yang dijelaskan oleh Sugiyono, bahwa metode survei digunakan untuk mendapatkan data dari tempat tertentu yang alamiah, tetapi peneliti melakukan perlakuan dalam pengumpulan data, misal dengan mengedarkan kuesioner, tes, wawancara terstruktur, dan sebagainya [20]. Kriyantono juga memaparkan bahwa dalam perkembangannya, metode survei memungkinkan menggunakan wawancara sebagai instrumen riset disamping kuesioner, masih menurut Kriyantono tujuan wawancara adalah untuk memperdalam analisis dan interpretasi data [8].

Sampel dalam penelitian ini adalah pegawai Dinas Budaya, Pariwisata, Pemuda dan Olah Raga di Kabupaten Gunung Mas Kalimantan Tengah yang berjumlah 33 (tiga puluh tiga) orang keadaan tahun 2014. Teknik pengumpulan data melalui penyebaran kuesioner yang berjumlah 20 pernyataan. Instrumen penelitian di uji sehingga diperoleh validitas dan reliabilitas soal. Analisis penelitian menggunakan uji Analisis Jalur (Path Analysis). Analisis data dilakukan dengan menggunakan aplikasi SPSS 19 for windows. 
HASIL DAN PEMBAHASAN

Analisis Deskriptif Iklim Komunikasi Organisasi Tabel 1

Rangkuman Iklim Komunikasi Organisasi Pegawai Pada Kantor Dinas Kebudayaan, Pariwisata, Pemuda dan Olah Raga Kabupaten Gunung Mas Kalimantan Tengah.

\begin{tabular}{|c|c|c|c|c|}
\hline $\begin{array}{c}\text { No } \\
\text {. }\end{array}$ & Pernyataan & $\begin{array}{l}\text { Total } \\
\text { Skor }\end{array}$ & Keterangan & $\begin{array}{l}\text { Total } \\
\text { Mean } \\
\text { Skor }\end{array}$ \\
\hline \multicolumn{5}{|c|}{ INDIKATOR 1: Kepercayaan } \\
\hline 1 & $\begin{array}{l}\text { Atasan Anda memiliki } \\
\text { kepercayaan kepada } \\
\text { Anda. }\end{array}$ & 130 & Setuju & 3,9 \\
\hline 2 & $\begin{array}{l}\text { Atasan Anda percaya } \\
\text { dengan kemampuan } \\
\text { dan hasil kerja Anda }\end{array}$ & 118 & Setuju & 3,5 \\
\hline 3 & $\begin{array}{lr}\text { Anda } & \text { memiliki } \\
\text { kepercayaan } & \text { kepada } \\
\text { atasan Anda } & \\
\end{array}$ & 109 & $\begin{array}{l}\text { Cukup } \\
\text { Setuju }\end{array}$ & 3,3 \\
\hline 4 & $\begin{array}{l}\text { Anda percaya dengan } \\
\text { kemampuan dan hasil } \\
\text { kerja atasan Anda }\end{array}$ & 116 & Setuju & 3,5 \\
\hline 5 & $\begin{array}{l}\text { Anda dan rekan kerja } \\
\text { satu tingkat saling } \\
\text { memiliki kepercayaan }\end{array}$ & 130 & Setuju & 4,0 \\
\hline 6 & $\begin{array}{lr}\text { Anda } & \text { memiliki } \\
\text { kepercayaan } & \text { pada } \\
\text { bawahan Anda } & \\
\end{array}$ & 116 & Setuju & 3,6 \\
\hline 7 & $\begin{array}{l}\text { Anda percaya dengan } \\
\text { kemampuan dan hasil } \\
\text { kerja bawahan Anda }\end{array}$ & 115 & Setuju & 3,6 \\
\hline 8 & $\begin{array}{l}\text { Bawahan Anda } \\
\text { memiliki kepercayaan } \\
\text { pada Anda }\end{array}$ & 114 & Setuju & 3,6 \\
\hline 9 & $\begin{array}{l}\text { Bawahan Anda percaya } \\
\text { dengan kemampuan } \\
\text { dan hasil kerja Anda }\end{array}$ & 122 & Setuju & 3,9 \\
\hline 10 & $\begin{array}{l}\text { Anda percaya dengan } \\
\text { kemampuan dan hasil } \\
\text { kerja rekan kerja Anda }\end{array}$ & 108 & $\begin{array}{l}\text { Cukup } \\
\text { Setuju }\end{array}$ & 3,5 \\
\hline & $\begin{array}{ll}\text { Rata-rata } & \text { skor } \\
\text { indikator } 1 & \\
\end{array}$ & 117,8 & Setuju & 3,6 \\
\hline \multicolumn{5}{|c|}{ INDIKATOR 2: Pembuat Keputusan Bersama } \\
\hline 11 & $\begin{array}{l}\text { Dalam setiap } \\
\text { pengambilan } \\
\text { keputusan, Anda selalu } \\
\text { diajak berdiskusi dan } \\
\text { konsultasi mengenai } \\
\text { kebijakan organisasi } \\
\text { yang relevan dengan } \\
\text { jabatan Anda }\end{array}$ & 108 & $\begin{array}{l}\text { Cukup } \\
\text { Setuju }\end{array}$ & 3,5 \\
\hline 18 & $\begin{array}{l}\text { Atasan Anda selalu } \\
\text { memiliki kesempatan } \\
\text { untuk mendengarkan } \\
\text { dan berdiskusi tentang } \\
\text { pendapat atau laporan } \\
\text { masalah yang diajukan } \\
\text { oleh Anda }\end{array}$ & 124 & Setuju & 4,2 \\
\hline & $\begin{array}{l}\text { Rata-rata skor } \\
\text { indikator } \mathbf{2}\end{array}$ & 116 & Setuju & 3,9 \\
\hline \multicolumn{5}{|c|}{ INDIKATOR 3: Dukungan } \\
\hline 13 & $\begin{array}{l}\text { Anda memberikan } \\
\text { dukungan pada setiap } \\
\text { kebijakan organisasi }\end{array}$ & 124 & Setuju & 4,0 \\
\hline 14 & $\begin{array}{l}\text { Organisasi mendukung } \\
\text { atas perbedaan } \\
\text { pendapat di antara } \\
\text { anggota organisasi }\end{array}$ & 118 & Setuju & 3,9 \\
\hline
\end{tabular}

\begin{tabular}{|c|c|c|c|c|}
\hline $\begin{array}{c}\text { No } \\
\text {. }\end{array}$ & Pernyataan & $\begin{array}{l}\text { Total } \\
\text { Skor }\end{array}$ & Keterangan & $\begin{array}{c}\text { Total } \\
\text { Mean } \\
\text { Skor }\end{array}$ \\
\hline \multirow[t]{2}{*}{15} & $\begin{array}{l}\text { Anda dapat } \\
\text { mengatakan "apa yang } \\
\text { ada dalam pikiran } \\
\text { Anda" terlepas dari } \\
\text { apakah Anda Berbicara } \\
\text { dengan atasan atau } \\
\text { bawahan }\end{array}$ & 136 & Setuju & 4,4 \\
\hline & $\begin{array}{l}\text { Rata-rata skor } \\
\text { indikator } 3\end{array}$ & 126 & Setuju & 4,1 \\
\hline \multicolumn{5}{|c|}{ INDIKATOR 4: Keterbukaan } \\
\hline 12 & $\begin{array}{l}\text { Anda diberi } \\
\text { kesempatan } \\
\text { menyampaikan } \\
\text { pendapat tentang } \\
\text { kebijakan organisasi } \\
\text { yang akan diambil oleh } \\
\text { Atasan Anda }\end{array}$ & 110 & $\begin{array}{l}\text { Cukup } \\
\text { Setuju }\end{array}$ & 3,6 \\
\hline 16 & $\begin{array}{l}\text { Kecuali terhadap } \\
\text { informasi untuk } \\
\text { keamanan yang } \\
\text { diperlukan, semua } \\
\text { karyawan memiliki } \\
\text { akses yang mudah } \\
\text { terhadap informasi } \\
\text { yang berkaitan } \\
\text { langsung dengan } \\
\text { pekerjaan mereka } \\
\end{array}$ & 115 & Setuju & 3,9 \\
\hline \multirow[t]{2}{*}{17} & $\begin{array}{l}\text { Semua karyawan } \\
\text { menerima informasi } \\
\text { tentang peningkatan } \\
\text { kemampuan kerja } \\
\text { untuk } \\
\text { mengoordinasikan } \\
\text { pekerjaannya dalam } \\
\text { organisasi }\end{array}$ & 111 & $\begin{array}{l}\text { Cukup } \\
\text { Setuju }\end{array}$ & 3,8 \\
\hline & $\begin{array}{l}\text { Rata-rata skor } \\
\text { indikator } 4\end{array}$ & 112 & Setuju & 3,9 \\
\hline \multicolumn{5}{|c|}{ INDIKATOR 5: Perhatian atas tujuan kinerja tinggi } \\
\hline 19 & $\begin{array}{l}\text { Anda selalu berusaha } \\
\text { menunjukkan } \\
\text { komitmen terhadap } \\
\text { organisasi untuk } \\
\text { berkinerja tinggi }\end{array}$ & 89 & Setuju & 3,2 \\
\hline \multirow[t]{4}{*}{20} & $\begin{array}{l}\text { Bagi organisasi atau } \\
\text { pihak kantor, } \\
\text { kesejahteraan semua } \\
\text { karyawan sangat } \\
\text { penting artinya untuk } \\
\text { meningkatkan kinerja } \\
\text { karyawan }\end{array}$ & 119 & Setuju & 4,2 \\
\hline & $\begin{array}{l}\text { Rata-rata skor } \\
\text { indikator } 5\end{array}$ & 105,7 & $\begin{array}{l}\text { Cukup } \\
\text { Setuju }\end{array}$ & 3,6 \\
\hline & $\begin{array}{l}\text { Total Skor Variabel } \\
\text { Iklim Komunikasi } \\
\text { Organisasi }\end{array}$ & 2332 & & 74,76 \\
\hline & Rata-rata Gabungan & & & 3,53 \\
\hline
\end{tabular}

Sumber : Rekap dari Hasil Pengolahan

Untuk menilai kriteria variabel iklim komunikasi organisasi pada Kantor Dinas Kebudayaan, Pariwisata, Pemuda dan Olah Raga Kabupaten Gunung Mas Kalimantan Tengah secara umum terlebih dahulu akan dibuat kriteria penilaian skor. Dengan jumlah skor tertinggi adalah $5 \times 20 \times 33=3300$, dan jumlah 
skor terendah adalah $1 \times 20 \times 33=660$. Klasifikasi skor jawaban pegawai dari variabel iklim komunikasi organisasi dapat digambarkan dalam tahapan bobot skor dengan rentang skor 528 sebagai berikut :

Tabel 2

Rentang Skala Penelitian Variabel Iklim Komunikasi Organisai

\begin{tabular}{|c|c|l|}
\hline No & Rentang Skala & \multicolumn{1}{|c|}{ Kriteria } \\
\hline 1 & $660-1187.99$ & Sangat Buruk/Sangat Rendah \\
\hline 2 & $1188-1715.99$ & Buruk/Rendah \\
\hline 3 & $1716-2243.99$ & Cukup Baik/Cukup Tinggi \\
\hline 4 & $\mathbf{2 2 4 4 - \mathbf { 2 7 7 1 . 9 9 }}$ & Baik/Tinggi \\
\hline 5 & $2772-3300$ & Sangat Baik/Sangat Tinggi \\
\hline
\end{tabular}

Sumber: Data diolah untuk keperluan penelitian

Berdasarkan bobot skor total variabel Iklim komunikasi organisasi pegawai pada Kantor Dinas Kebudayaan, Pariwisata, Pemuda dan Olah Raga Kabupaten Gunung Mas Kalimantan Tengah tergolong tinggi yaitu sebesar 2332, apabila dilihat pada table 5.7 diatas ternyata variabel iklim komunikasi organisasi termasuk pada rentang 2244-2771,99 berada pada Kriteria Baik artinya pelaksanaan iklim komunikasi organisasi pada Dinas Kebudayaan, Pariwisata, Pemuda dan Olah Raga Kabupaten Gunung Mas Kalimantan Tengah dikategorikan baik.

Berdasarkan skor total rata-rata tabel 5.6 di atas, nilai iklim komunikasi organisasi pada Dinas Kebudayaan, Pariwisata, Pemuda dan Olah Raga Kabupaten Gunung Mas Kalimantan Tengah memperoleh nilai gabungan 3,53. Nilai ini termasuk nilai yang lebih rendah dalam rentang nilai iklim komunikasi yang dikehendaki. Nilai iklim gabungan untuk organisasi yang sebanding adalah 3,83 , dan nilai iklim yang rendah atau tidak dikehendaki cenderung sekitar 2,80 dan lebih kecil lagi [3]. Namun, nilai gabungan keseluruhan inidikator sebesar 3,53, masih lebih tinggi daripada 2,80 yang merupakan tingkat nilai yang tidak dikehendaki.

Nilai gabungan indikator iklim komunikasi organisasi pegawai menunjukkan nilai paling tinggi pada nilai indikator 3 yaitu dukungan $(4,1)$ sedangkan nilai paling rendah pada indikator indikator 1 dan indikator 5 masing-masing memperoleh $(3,6)$. Ini menunjukkan bahwa faktor dukungan sangat diperlukan untuk menunjang kinerja pegawai pada Dinas Kebudayaan, Pariwisata, Pemuda dan Olah Raga Kabupaten Gunung Mas Kalimantan Tengah.

Skor tertinggi berada pada pernyataan Indikator "dukungan". Hal ini menyatakan bahwasanya Indikator dukungan pada Dinas Kebudayaan, Pariwisata, Pemuda dan Olah Raga Kabupaten Gunung Mas Kalimantan Tengah dapat terlaksana dengan baik guna untuk memberi dorongan kepada pegawai dalam meningkatkan kinerjanya, yakni berupa perhatian atau dukungan organisasi pada karyawannya dan dukungan karyawan pada organisasinya. Sedangkan untuk skor yang paling rendah berada pada pernyataan Indikator "Perhatian pada tujuan kinerja yang tinggii", yang merupakan kebutuhan dasar pegawai dalam mendukung pekerjaannya, yang dirasa agak rendah belum begitu memuaskan, belumlah sesuai seperti yang diharapkan oleh pegawai.

\section{Analisis Deskriptif Efektivitas Komunikasi Interpersonal}

Tabel 3

Rangkuman Efektivitas Komunikasi Interpersonal Pegawai Pada Kantor Dinas Kebudayaan, Pariwisata, Pemuda Dan Olah Raga Kabupaten Gunung Mas Kalimantan Tengah.

\begin{tabular}{|c|c|c|c|c|}
\hline No & Pernyataan & $\begin{array}{l}\text { Total } \\
\text { Skor }\end{array}$ & Keterangan & $\begin{array}{l}\text { Total } \\
\text { Mean } \\
\text { Skor }\end{array}$ \\
\hline \multicolumn{5}{|c|}{ INDIKATOR 1: Keterbukaan } \\
\hline 21 & $\begin{array}{l}\text { Anda bersikap terbuka } \\
\text { kepada org yang diajak } \\
\text { berinteraksi }\end{array}$ & 139 & Setuju & 4,12 \\
\hline \multicolumn{5}{|c|}{ INDIKATOR 2: Empati } \\
\hline 22 & $\begin{array}{l}\text { Anda peka dengan apa } \\
\text { yang dialami orang lain } \\
\text { pada suatu saat } \\
\text { tertentu, dari sudut } \\
\text { pandang orang lain itu } \\
\text { melalui kacamata } \\
\text { orang lain itu }\end{array}$ & 125 & Setuju & 3,74 \\
\hline \multicolumn{5}{|c|}{ INDIKATOR 3: Sikap Mendukung } \\
\hline 23 & $\begin{array}{l}\text { Dalam suasana yang } \\
\text { tidak medukung, } \\
\text { komunikasi yang } \\
\text { terbuka dan empati } \\
\text { tidak dapat } \\
\text { berlangsung }\end{array}$ & 144 & Setuju & 4,32 \\
\hline \multicolumn{5}{|c|}{ INDIKATOR 4: Sikap Positif } \\
\hline 24 & $\begin{array}{l}\text { Perasaan positif untuk } \\
\text { situasi komunikasi } \\
\text { pada umumnya sangat } \\
\text { penting untuk interaksi } \\
\text { yang efektif }\end{array}$ & 106 & Cukup Setuju & 3,24 \\
\hline \multicolumn{5}{|c|}{ INDIKATOR 5: Kesetaraan } \\
\hline \multirow[t]{3}{*}{25} & $\begin{array}{l}\text { Adanya pengakuan di } \\
\text { antara karyawan } \\
\text { bahwa masing-masing } \\
\text { pihak bernilai dan } \\
\text { berharga, serta } \\
\text { mempunyai sesuatu } \\
\text { yang penting untuk } \\
\text { disumbangkan. }\end{array}$ & 124 & Setuju & 3,79 \\
\hline & $\begin{array}{l}\text { Total Skor Variabel } \\
\text { Efektivitas Komunikasi } \\
\text { Interpersonal }\end{array}$ & 638 & & 19,21 \\
\hline & Rata-rata & & & 3,87 \\
\hline
\end{tabular}

Sumber : Rekap dari Hasil Pengolahan

Untuk menilai kriteria variabel efektivitas komunikasi interpersonal pada Kantor Dinas Kebudayaan, Pariwisata, Pemuda dan Olah Raga Kabupaten Gunung Mas Kalimantan Tengah secara umum terlebih dahulu akan dibuat kriteria penilaian skor. Dengan jumlah skor tertinggi adalah $5 \times 5 \times 33=$ 825 , dan jumlah skor terendah adalah $1 \times 5 \times 33=165$. Klasifikasi skor jawaban pegawai dari variabel efektivitas komunikasi interpersonal dapat digambarkan dalam tahapan bobot skor dengan rentang skor 132 sebagai berikut: 
Tabel 4

Rentang Skala Penelitian Variabel Iklim Komunikasi Organisai

\begin{tabular}{|c|c|l|}
\hline No & Rentang Skala & \multicolumn{1}{|c|}{ Kriteria } \\
\hline 1 & $165-296.99$ & Sangat Buruk/Sangat Rendah \\
\hline 2 & $297-438.99$ & Buruk/Rendah \\
\hline 3 & $429-560.99$ & Cukup Baik/Cukup Tinggi \\
\hline 4 & $\mathbf{5 6 1 - 6 9 2 . 9 9}$ & Baik/Tinggi \\
\hline 5 & $693-825$ & Sangat Baik/Sangat Tinggi \\
\hline
\end{tabular}

Sumber: Data diolah untuk keperluan penelitian

Berdasarkan bobot skor total variabel Iklim komunikasi organisasi pegawai pada Kantor Dinas Kebudayaan, Pariwisata, Pemuda dan Olah Raga Kabupaten Gunung Mas Kalimantan Tengah tergolong tinggi yaitu sebesar 638, apabila dilihat pada table 5.14 diatas ternyata variabel efektivitas komunikasi interpersonal termasuk pada rentang 561-692.99 berada pada Kriteria Baik artinya pelaksanaan efektivitas komunikasi organisasi pada Dinas Kebudayaan, Pariwisata, Pemuda dan Olah Raga Kabupaten Gunung Mas Kalimantan Tengah dikategorikan baik.

Berdasarkan skor total rata-rata tabel 5.14 di atas, nilai efektivitas komunikasi interpersonal pada Dinas Kebudayaan, Pariwisata, Pemuda dan Olah Raga Kabupaten Gunung Mas Kalimantan Tengah memperoleh nilai gabungan 3,87. Nilai ini termasuk nilai yang lebih tinggi dalam rentang nilai efektivitas komunikasi interpersonal yang dikehendaki. Nilai iklim gabungan untuk organisasi yang sebanding adalah 3,83, dan nilai iklim yang rendah atau tidak dikehendaki cenderung sekitar 2,80 dan lebih kecil lagi [3].

Nilai gabungan indikator efektivitas komunikasi interpersonal pegawai menunjukkan nilai paling tinggi pada nilai indikator 1 yaitu keyterbukaan $(4,12)$ sedangkan nilai paling rendah pada indikator indikator $4(3,24)$. Ini menunjukkan bahwa faktor keterbukaan sangat diperlukan untuk menunjang kinerja pegawai pada Dinas Kebudayaan, Pariwisata, Pemuda dan Olah Raga Kabupaten Gunung Mas Kalimantan Tengah

Skor tertinggi berada pada pernyataan Indikator "sikap mendukung". Hal ini menyatakan Indikator sikap mendukung pada Dinas Kebudayaan, Pariwisata, Pemuda dan Olah Raga Kabupaten Gunung Mas Kalimantan Tengah dapat terlaksana dengan baik guna untuk memberi dorongan kepada pegawai dalam meningkatkan kinerjanya, yakni berupa komunikasi yang terbuka dan empatik tidak dapat berlangsung dalam suasana yang tidak mendukung. Sedangkan untuk skor yang paling rendah berada pada pernyataan Indikator "sikap positif", yang merupakan kebutuhan pegawai dalam mendukung pekerjaannya, yang dirasa agak rendah belum begitu memuaskan, belumlah sesuai seperti yang diharapkan oleh pegawai.

\section{Analisis Deskriptif Kepuasan Kerja Tabel 5}

Rangkuman Kepuasan Kerja Pegawai Pada Kantor Dinas Kebudayaan, Pariwisata, Pemuda dan Olah Raga Kabupaten Gunung Mas Kalimantan Tengah.

\begin{tabular}{|c|c|c|c|c|}
\hline No & Pernyataan & $\begin{array}{l}\text { Total } \\
\text { Skor }\end{array}$ & Keterangan & $\begin{array}{c}\text { Total } \\
\text { Mean } \\
\text { Skor }\end{array}$ \\
\hline \multicolumn{5}{|c|}{ INDIKATOR 1: Kepuasan terhadap gaji } \\
\hline 26 & $\begin{array}{l}\text { Tunjangan-tunjangan } \\
\text { lain di luar gaji } \\
\text { seperti bonus, } \\
\text { asuransi jiwa dan } \\
\text { kesehatan, } \\
\text { tunjangan hari raya } \\
\text { yang diberikan oleh } \\
\text { organisasi pada Anda } \\
\text { atas penghargaan } \\
\text { hasil kerja yang Anda } \\
\text { lakukan dengan baik } \\
\text { dan memuaskan }\end{array}$ & 143 & Setuju & 4,33 \\
\hline \multicolumn{5}{|c|}{ INDIKATOR 2: Kepuasan terhadap promosi } \\
\hline 27 & $\begin{array}{l}\text { Kesempatan yang } \\
\text { sama bagi setiap } \\
\text { karyawan untuk } \\
\text { dipromosikan atas } \\
\text { prestasi yang } \\
\text { dihasilkan }\end{array}$ & 125 & Setuju & 3,79 \\
\hline \multicolumn{5}{|c|}{ INDIKATOR 3: Kepuasan terhadap rekan kerja } \\
\hline 28 & $\begin{array}{l}\text { Sikap yang saling } \\
\text { mendukung dan } \\
\text { membantu dari } \\
\text { rekan-rekan kerja } \\
\text { Anda }\end{array}$ & 143 & Setuju & 4,33 \\
\hline \multicolumn{5}{|c|}{$\begin{array}{l}\text { INDIKATOR 4: Kepuasan terhadap } \\
\text { supervise/pengawasan }\end{array}$} \\
\hline 29 & $\begin{array}{l}\text { Peluang yang } \\
\text { diberikan oleh } \\
\text { organisasi kepada } \\
\text { Anda untuk memiliki } \\
\text { kebebasan dalam } \\
\text { bekerja sendiri dan } \\
\text { tidak diawasi secara } \\
\text { ketat }\end{array}$ & 109 & $\begin{array}{l}\text { Cukup } \\
\text { Setuju }\end{array}$ & 3,30 \\
\hline \multicolumn{5}{|c|}{ INDIKATOR 5: Kepuasan terhadap pekerjaan } \\
\hline \multirow[t]{3}{*}{30} & $\begin{array}{l}\text { Kecocokan yang } \\
\text { tinggi antara } \\
\text { kepribadian anda } \\
\text { dan pekerja lainnya } \\
\text { sehingga anda } \\
\text { merasa puas dengan } \\
\text { pekerjaan anda.. }\end{array}$ & 133 & Setuju & 4,03 \\
\hline & $\begin{array}{l}\text { Total Skor Variabel } \\
\text { Kepuasan Kerja }\end{array}$ & 653 & & 19,79 \\
\hline & Rata-rata & & & 3,96 \\
\hline
\end{tabular}

Sumber: Rekap dari Hasil Pengolahan

Untuk menilai kriteria variabel kepuasan kerja pada Kantor Dinas Kebudayaan, Pariwisata, Pemuda dan Olah Raga Kabupaten Gunung Mas Kalimantan Tengah secara umum terlebih dahulu akan dibuat kriteria penilaian skor. Dengan jumlah skor tertinggi adalah $5 \times 5 \times 33=825$, dan jumlah skor terendah adalah $1 \times 5 \times 33=165$. Klasifikasi skor jawaban pegawai dari variabel kepuasan kerja dapat digambarkan dalam tahapan bobot skor dengan 
rentang skor 132 sebagai berikut:

Tabel 6

Rentang Skala Penelitian Variabel Kepuasan Kerja

\begin{tabular}{|c|c|l|}
\hline No & Rentang Skala & \multicolumn{1}{|c|}{ Kriteria } \\
\hline 1 & $165-296.99$ & Sangat Buruk/Sangat Rendah \\
\hline 2 & $297-438.99$ & Buruk/Rendah \\
\hline 3 & $429-560.99$ & Cukup Baik/Cukup Tinggi \\
\hline 4 & $\mathbf{5 6 1 - 6 9 2 . 9 9}$ & Baik/Tinggi \\
\hline 5 & $693-825$ & Sangat Baik/Sangat Tinggi \\
\hline
\end{tabular}

Sumber: Data diolah untuk keperluan penelitian kepuasan kerja pegawai pada Kantor Dinas Kebudayaan, Pariwisata, Pemuda dan Olah Raga Kabupaten Gunung Mas Kalimantan Tengah tergolong tinggi yaitu sebesar 638, apabila dilihat pada table 6 diatas ternyata variabel kepuasan kerja termasuk pada range 561 - 692.99 berada pada Kriteria Baik artinya kepuasan kerja pegawai pada Dinas Kebudayaan, Pariwisata, Pemuda dan Olah Raga Kabupaten Gunung Mas Kalimantan Tengah dikategorikan baik.

Berdasarkan skor total rata-rata tabel 5.20 di atas, nilai kepuasan kerja pada Dinas Kebudayaan, Pariwisata, Pemuda dan Olah Raga Kabupaten Gunung Mas Kalimantan Tengah memperoleh nilai gabungan 3,96 . Nilai ini termasuk nilai yang lebih rendah dalam rentang nilai kepuasan kerja yang dikehendaki. Nilai kepuasan kerja terhadap organisasi yang menandai pegawai dalam organisasi yang efektif adalah 4,00. Tingkat kepuasan yang lebih tinggi mendukung pegawai untuk lebih menyukai kepuasan daripada kinerja. Dan Nilai kepuasan yang rendah atau tidak dikehendaki cenderung sekitar 2,80 dan lebih kecil lagi [3]. Namun, nilai gabungan keseluruhan inidikator sebesar 3,96, masih lebih tinggi daripada 2,80 yang merupakan tingkat nilai yang tidak dikehendaki. Jadi, nilai kepuasan kerja pada pada Dinas Kebudayaan, Pariwisata, Pemuda dan Olah Raga Kabupaten Gunung Mas Kalimantan Tengah menunjukkan nilai yang mendekati nilai yang dikehendaki dalam organisasi.

Nilai gabungan indikator kepuasan kerja pegawai menunjukkan nilai paling tinggi pada nilai indikator 1 dan indikator 3 yaitu $(4,33)$ sedangkan nilai paling rendah pada indikator indikator 2 memperoleh $(3,6)$. Ini menunjukkan bahwa faktor gaji dan rekan kerja sangat diperlukan untuk menunjang kinerja pegawai pada Dinas Kebudayaan, Pariwisata, Pemuda dan Olah Raga Kabupaten Gunung Mas Kalimantan Tengah

Skor tertinggi berada pada pernyataan Indikator "kepuasan terhadap gaji" dan "kepuasan terhadap rekan kerja". Hal ini menyatakan kedua Indikator tersebut di Dinas Kebudayaan, Pariwisata, Pemuda dan Olah Raga Kabupaten Gunung Mas Kalimantan Tengah dapat terlaksana dengan baik guna untuk memberi dorongan kepada pegawai dalam meningkatkan kinerjanya, yakni berupa perhatian atau dukungan organisasi pada karyawannya dan dukungan karyawan terhadap karyawan. Sedangkan untuk skor yang paling rendah berada pada pernyataan Indikator "kepuasan terhadap pengawasan", pegawai merasa kurang nyaman jika atasan atau rekan kerja yang lain mengawai kinerja dalam mendukung pekerjaannya, yang dirasa agak rendah belum begitu memuaskan, belumlah sesuai seperti yang diharapkan oleh pegawai.

\section{Pengujian Hipotesis \\ Pengaruh Iklim Komunikasi Organisasi (X1) terhadap Efektivitas Komunikasi Interpersonal (Y1)}

Hipotesis yang akan dibuktikan yaitu "ada pengaruh iklim komunikasi terhadap efektivitas komunikasi interpersonal. Ringkasan hasil pengujian data SPSS dapat dilihat pada tabel 7 berikut:

Tabel 7

Hasil Analisis Pengaruh Iklim Komunikasi Organisasi Terhadap Efektivitas Komunikasi Interpersonal

\begin{tabular}{|c|l|c|c|c|}
\hline \multicolumn{2}{|c|}{ Variabel } & $\begin{array}{l}\text { Standardized } \\
\text { Coefficient }\end{array}$ & Sig & Keterangan \\
\hline \multicolumn{1}{|c|}{ Bebas } & \multicolumn{1}{|c|}{ Terikat } & Beta & Signifikan \\
\hline $\begin{array}{l}\text { Iklim } \\
\text { Komunikasi }\end{array}$ & $\begin{array}{l}\text { Efektivitas } \\
\text { Komunikasi } \\
\text { Interpersonal }\end{array}$ & 0.290 & 0.026 & sign \\
\hline
\end{tabular}

Berdasarkan hasil hipotesis dapat diketahui bahwa besarnya koefesien pengaruh komunikasi (X) terhadap efektivitas komunikasi interpersonal (Y1) yang ditunjukkan oleh nilai Standardized Coefecient/Beta adalah 0.290. taraf signifikannya adalah 0.026 (pada $\alpha=0.05$ ). Oleh karena taraf signifikansinya lebih kecil dari 0.05 dan nilai Standardized Coefecient/Beta menunjukkan tanda positif, maka ada pengaruh langsung iklim komunikasi terhadap efektivitas komunikasi interpersonal" sehingga dapat disimpulkan bahwa iklim komunikasi organisasi berpengaruh positif dan signifikan terhadap efektivitas komunikasi interpersonal di Dinas Kebudayaan, Pariwisata, Pemuda dan Olah Raga Kabupaten Gunung Mas Kalimantan Tengah.

Berdasarkan Tabel hasil analisis pada tabel 7 dapat diketahui pada taraf signifikannya yaitu 0.026 , ini menunjukkan bahwa ada pengaruh positif dan signifikan iklim komunikasi organisasi terhadap efektivitas komunikasi interpersonal. Pernyataan ini sesuai dengan penelitian dari [21] juga menguji hal serupa dengan bukti empiris terdapat hubungan positif dan signifikan antara iklim organisasi dengan komunikasi karyawan. Sidarta (2000) menguji faktorfaktor yang mempengaruhi iklim organisasi meliputi: (1) praktek pengambilan keputusan, (2) arus komunikasi, (3) kondisi motivasi, (4) keunggulan sumber daya manusia dan (5) kesiapan teknologi. Lebih lanjut menurut [22], keberhasilan suatu organisasi dengan membentuk iklim yang kondusif akan mampu mempengaruhi komunikasi karyawan sehingga akan meningkatkan kinerja karyawan (job performance). Sementara Miner (1988) dalam [23] mengatakan bahwa komunikasi karyawan terhadap organisasinya banyak dipengaruhi oleh persepsi karyawan terhadap manajemen, iklim organisasi, dan sistem kerja organisasi yang bersangkutan. Dari 
pandangan tersebut dapat dikatakan bahwa iklim organisasi berpengaruh terhadap komunikasi interpersonal dalam organisasi.

\section{Pengaruh Iklim Komunikasi Organisasi (X1) terhadap Kepuasan Kerja (Y2)}

Hipotesis yang akan dibuktikan yaitu "ada pengaruh langsung iklim komunikasi terhadap kepuasan kerja. Ringkasan hasil pengujian data SPSS dapat dilihat pada tabel 8 berikut:

Tabel 8

Hasil Analisis Pengaruh Iklim Komunikasi Organisasi Terhadap Kepuasan Kerja

\begin{tabular}{|c|c|c|c|c|}
\hline \multicolumn{2}{|l|}{ Variabel } & \multirow{2}{*}{$\begin{array}{c}\text { Standardized } \\
\text { Coefficient } \\
\text { Beta }\end{array}$} & \multirow{2}{*}{ Sig } & \multirow{2}{*}{ Keterangan } \\
\hline Bebas & Terikat & & & \\
\hline \begin{tabular}{|l|} 
Iklim \\
Komunikasi
\end{tabular} & $\begin{array}{l}\text { Kepuasan } \\
\text { Kerja }\end{array}$ & 0.317 & 0.036 & signifikan \\
\hline
\end{tabular}

Berdasarkan hasil hipotesis dapat diketahui bahwa besarnya koefesien pengaruh komunikasi (X) terhadap kepuasan kerja (Y2) yang ditunjukkan oleh nilai Standardized Coefecient/Beta adalah 0.317. taraf signifikannya adalah 0.036 (pada $\alpha=0.05$ ). oleh karena taraf signifikansinya lebih kecil dari 0.05 dan nilai Standardized Coefecient/Beta menunjukkan tanda positif, maka ada pengaruh langsung iklim komunikasi terhadap kepuasan kerja" sehingga dapat disimpulkan bahwa iklim komunikasi organisasi berpengaruh positif dan signifikan terhadap kepuasan kerja di Dinas Kebudayaan, Pariwisata, Pemuda dan Olah Raga Kabupaten Gunung Mas Kalimantan Tengah.

Iklim komunikasi merupakan persepsipersepsi mengenai pesan dan peristiwa yang berhubungna dengan apa yang terjadi dalam perusahaan. Di pihak lain, iklim komunikasi dapat dikatakan juga sebagai gabungan dari persepsipersepsi mengenai peristiwa komunikasi, perilaku manusia, respon anggota terhadap anggota lainnya, harapan-harapan, konflik-konflik antar personal, dan kesempatan bagi pertumbuhan dalam organisasi tersebut [3].

Denis mendefinisikan iklim komunikasi sebagai kualitas pengalaman subjektif dari lingkungan internal sebuah organisasi yang mencakup persepsi dari lingkungan internal sebuah organisasi yang mencakup persepsi dari pesan dan peristiwa yang terkait dengan pesan yang terjadi dalam organisasi [24]. Iklim komunikasi dapat juga dipandang sebagai suatu kualitas pengalaman yang subjektif yang timbul dari persepsi pegawai terhadap karakteristik dalam organisasi [25].

Redding berpendapat bahwa iklim komunikasi jauh lebih penting daripada keterampilan atau teknik-teknik komunikasi semata dalam menciptakan suatu organisasi yang efektif [24]. Redding juga mengatakan bahwa organisasi untuk menunjukkan kepada para pegawai bahwa organisasi tersebut mempercayai mereka, dan memberi mereka kebebasan dalam mengambil resiko; mendorong dan member mereka tanggung jawab dalam mengerjakan tugas-tugas mereka; menyediakan informasi yang terbuka dana memadai tentang organisasi; mendegarkan denga penuh perhatian serta memperoleh informasi yang dapat dipercaya dan terus terang dari pegawai; secara aktif memberikan penyuluhan kepada karyawan sehingga mereka dapat melihat bahwa keterlibatan mereka penting bagi keputusan-keputusan dalam organisasi; dan menaruh perhatian pada pekerjaan yang bermutu tinggi dan memberi tantangan [26].

Berdasarkan Tabel hasil analisis pada tabel 8 dapat diketahui dari pada taraf signifikannya adalah 0.036, ini menunjukkan bahwa ada pengaruh positif dan signifikan iklim komunikasi organisasi terhadap kepuasan kerja. Pernyataan ini sesuai dengan penelitian dari [27] yang berjudul pengaruh iklim komunikasi organisasi terhadap produktivitas kerja karyawan, yang menyatakan terdapat hubungan yang fungsional dan linear iklim komunikasi organisasi terhadap produktivitas kerja karyawan, disamping itu beliau juga menyatakan untuk dapat meningkatkan produktivitas kerja karyawan suatu perusahaan perlu memperhatikan iklim komunikasi organisasi.

Iklim komunikasi merupakan persepsipersepsi mengenai pesan dan peristiwa yang berhubungna dengan apa yang terjadi dalam perusahaan. Di pihak lain, iklim komunikasi dapat dikatakan juga sebagai gabungan dari persepsipersepsi mengenai peristiwa komunikasi, perilaku manusia, respon anggota terhadap anggota lainnya, harapan-harapan, konflik-konflik antar personal, dan kesempatan bagi pertumbuhan dalam organisasi tersebut [3].

Penelitian [7] yang menyatakan iklim komunikasi organisasi merupakan suatu syarat bagi peningkatan produktivitas dan prestasi kerja organisasi, sehingga secara tidak langsung akan berhubungan dengan pencapaian tujuan organisasi. Hal ini terjadi karena apabila karyawan memiliki komunikasi yang yang efektif dalam organisasi maka akan muncul loyalitas kepada organisasi dan menjalin hubungan aktif dan saling mendukung dalam mencapai tujuan organisasi yang bersangkutan. Selain itu, komunikasi yang efektif menyebabkan mereka akan bekerja, bersikap dan berperilaku baik dan keras untuk organisasi.

Pengaruh Efektivitas Komunikasi Interpersonal (Y1) terhadap Kepuasan Kerja (Y)

Asumsinya yaitu ada pengaruh langsung efektivitas komunikasi interpersonal terhadap kepuasan kerja". Ringkasan hasil pengujian koefisien jalur data SPSS dapat dililhat pada tabel 9 berikut: 
Tabel 9

Hasil Analisis Pengaruh Efektivitas Komunikasi Interpersonal Terhadap Kepuasan Kerja

\begin{tabular}{|l|l|c|l|l|}
\hline \multicolumn{2}{|c|}{ Variabel } & $\begin{array}{c}\text { Standardized } \\
\text { Coefficient }\end{array}$ & Sig & Keterangan \\
\hline \multicolumn{1}{|c|}{ Bebas } & Terikat & Beta & & \\
\hline $\begin{array}{l}\text { Efektivitas } \\
\text { komunikasi } \\
\text { interpersonal }\end{array}$ & $\begin{array}{l}\text { kepuasan } \\
\text { kerja }\end{array}$ & 0.541 & 0.001 & signifikan \\
\hline
\end{tabular}

Berdasarkan hasil hipotesis dapat diketahui bahwa besarnya koefesien pengaruh efektivitas komunikasi interpersonal (Y1) terhadap kepuasan kerja (Y2) yang ditunjukkan oleh nilai Standardized Coefecient/Beta adalah 0.541. taraf signifikannya adalah 0.001 (pada $\alpha=0.05$ ). oleh karena taraf signifikansinya lebih kecil dari 0.05 dan nilai Standardized Coefecient/Beta menunjukkan positif maka, ada pengaruh langsung efektivitas komunikasi interpersonal terhadap kepuasan kerja" sehingga dapat disimpulkan bahwa efektivitas komunikasi interpersonal berpengaruh positif dan signifikan terhadap kepuasan kerja pegawai di Dinas Kebudayaan, Pariwisata, Pemuda dan Olah Raga Kabupaten Gunung Mas Kalimantan Tengah.

Komunikasi interpersonal adalah komunikasi yang dilakukan dengan orang lain, dan merupakan sebuah metode komunikasi yang sering digunakan oleh manusia pada saat bekerja, bergaul dan bermasyarakat. Miskinnya kecakapan komunikasi merupakan masalah yang sering dihadapi oleh semua orang [28]. Komunikasi interpersonal yang efektif apabila pesan diterima dan dimengerti sebagaimana dimaksud oleh pengirim pesan, pesan ditindaklanjuti dengan sebuah perbuatan secara suka rela oleh penerima pesan, dapat meningkatkan kualitas hubungan antarpribadi, dan tidak ada hambatan untuk hal itu [29].

Berdasarkan Tabel hasil analisis pada tabel 9 dapat diketahui dari pada taraf signifikannya adalah 0.001 , ini menunjukkan bahwa ada pengaruh positif dan signifikan efektivitas komunikasi interpersonal terhadap kepuasan kerja pegawai di Dinas Kebudayaan, Pariwisata, Pemuda dan Olah Raga Kabupaten Gunung Mas Kalimantan Tengah. Pernyataan ini sesuai dengan penelitian dari [30] yang berjudul efektivitas komunikasi interpersonal pada dinas kebudayaan dan pariwsata Provinsi Riau, yang menyatakan terdapat hubungan yang linear efektivitas komunikasi interpersonal terhadap produktivitas kerja karyawan, disamping itu Kurniawan juga menyatakan faktor-faktor yang berhubungan dengan dengan efektivitas komunikasi interpersonal yang positif tentang adanya faktor keterbukaan, empati, sikap mendukung, sikap positif dan kesataraan dalam kegiatan komunikasi interpersonal yang dilakukan pada organisasi. Lebih lanjtu [31] dalam penelitiannya yang berjudul efektivitas komunikasi interpersonal dengan tingkat kepuasan kerja karyawan menyatakan efektivitas komunikasi interpersonal memiliki kesetaraan terhadap kepuasan kerja yang mempunyai hubungan yang kuat dan positif

\section{Pengaruh Iklim Komunikasi (X) terhadap Kepuasan Kerja (Y2) Melalui Efektivitas Komunikasi Interpersonal (Y1)}

Hipotesis yang akan dibuktikan yaitu "ada pengaruh tidak langsung iklim komunikasi organisasi terhadap kepuasan kerja melalui efektivitas komunikasi interpersonal". Pengujian ini dilakukan melalui dua blok jalur, yang menguji iklim komunikasi organisasi (X) terhadap kepuasan kerja (Y2) yang hasilnya dapat dilihat pada pengujian hipotesis satu. Sedangkan blok jalur yang akan diuji selanjutnya adalah blok yang menguji pengaruh iklim komunikasi organisasi (X) terhadap efektivitas komunikasi interpersonal (X2) pengujian masing-masing blok jalur tersebut dapat kita lihat pada tabel 10 berikut:

Tabel 10

Pengaruh Iklim Komunikasi Organisasi terhadap Kepuasan Kerja Melalui Efektivitas Komunikasi Interpersonal

\begin{tabular}{|c|c|c|c|c|}
\hline \multicolumn{2}{|c|}{ Variabel } & \multirow{2}{*}{$\begin{array}{c}\text { Standardized } \\
\text { Coefficient }\end{array}$} & \multirow{2}{*}{ Sig } & \multirow[t]{2}{*}{ Keterangan } \\
\hline Bebas & Terikat & & & \\
\hline $\begin{array}{l}\text { Iklim } \\
\text { komunikasi } \\
\text { organisasi }\end{array}$ & $\begin{array}{l}\text { Efektivitas } \\
\text { komunikasi } \\
\text { interpersonal }\end{array}$ & 0.317 & 0.036 & Signifikan \\
\hline $\begin{array}{l}\text { Efektivitas } \\
\text { komunikasi } \\
\text { interpersonal }\end{array}$ & $\begin{array}{l}\text { Kepuasan } \\
\text { kerja }\end{array}$ & 0.541 & .000 & \\
\hline
\end{tabular}

Berdasarkan hasil pengujian hipotesis dapat

diketahui bahwa besarnya koefisien pengaruh iklim komunikasi organisasi (X) terhadap efektivitas komunikasi interpersonal (Y1) yang ditunjukkan oleh Standardized Coefocient/Beta adalah 0.317. taraf signifikansinya adalah 0.036 (pada $\alpha=0.05$ ). oleh karena taraf signifikan lebih kecil dari 0.05 maka "iklim komunikasi organisasi berpengaruh positif dan signifikan terhadap efektivitas komunikasi interpersonal"

Dari hasil pengujian pada terlihat bahwa ada pengaruh positif dan signifikan antara iklim komunikasi organisassi $(\mathrm{X})$ dan efektivitas komunikasi interpersonal (Y1) terhadap kepuasan kerja (Y2). Hasil pengujian ini memperlihatkan adanya pengaruh tidak langsung iklim komunikasi organisasi (X) terhadap kepuasan kerja (Y2) melalui efektivitas komunikasi interpersonal (Y1). Dimana besarnya pengaruh tidak langsung ini dapat ditentukan dengan mengalikan koefisien jalurnya yaitu $\mathrm{py}_{1} \times \mathrm{pyx}_{2}=0.317 \times 0.541=$ 0.171. Sehingga dapat disimpulkan bahwa ada pengaruh tidak langsung iklim komunikasi organisasi terhadap kepuasan kerja melalui efektivitas komunikasi interpersonal adalah sebesar 0.171 atau $17,1 \%$. 
Setelah melakukan pengujian di atas, maka dapat di gambarkan diagram jalur lengkap pengaruh X1 terhadap Y2 melalui Y1 sebagai berikut:

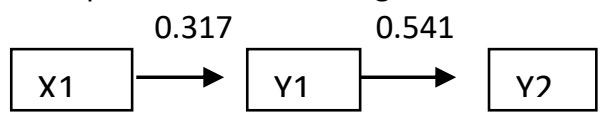

\section{PENGUJIAN MEDIASI}

Setelah melakukan pengujian, maka dapat digambarkan model diagramkan model diagram jalur akhir pengaruh iklim komunikasi organisasi (X1) dan efektivitas komunikasi interpersonal (X2) terhadap kepuasan kerja (Y) sebagai berikut:

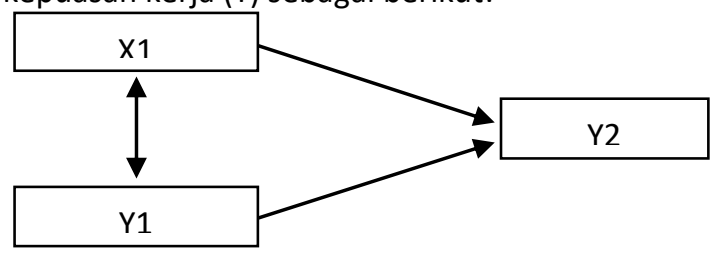

Dari diagram jalur di atas dapat dilihat bahwa semua asumsi yang diajukan diterima. Dari seluruh model di atas kemudian dilakukan dengan menggunakan koefesien jalur untuk menentukan jalur variabel eksogen terhadap variabel endogen. Model yang dapat dilakukan adalah sebagai berikut:

$Y_{1}=p_{1} x_{1} X_{1}+p y x_{2} X_{2}+\epsilon_{1}$ (persamaan struktur) $Y_{1}=0.317 X_{1}+0.541 X_{2}+0.832$

Dengan melihat pengaruh secara simultan yaitu pengaruh iklim komunikasi organiasasi dan efektivitas komunikasi interpersonal berpengaruh secara gabungan atau simultan terhadap kepuasan kerja, dengan melihat hasil perhitungan model summary yaitu $\mathrm{R}$ square di bawah ini:

Model
\begin{tabular}{|c|c|c|c|c|}
\hline M & R Square & $\begin{array}{c}\text { Adjusted R } \\
\text { Square }\end{array}$ & $\begin{array}{c}\text { Std. Error of the } \\
\text { Estimate }\end{array}$ \\
\hline 1 & $.613^{\mathrm{a}}$ & .376 & .334 & 1.220 \\
\hline
\end{tabular}

a. Predictors: (Constant), EFEKTIVITAS, IKLIM

b. Dependent Variable: KEPUASAN

Besarnya angka $R$ square $\left(r^{2}\right)$ adalah 0.376. Angka tersebut digunakan untuk melihat besarnya pengaruh iklim komunkasi organisasi (X1) dan efektivitas komunikasi interpersonal (X2) terhadap kepuasan kerja (Y) yaitu dengan cara menghitung koefisien (KD) dengan menggunakan rumus sebagai berikut:

$$
\begin{aligned}
& K D=r^{2} \times 100 \% \\
& K D=0.376 \times 100 \% \\
& K D=37.6 \%
\end{aligned}
$$

Dari hasil di atas bahwa ada pengaruh iklim komunikasi organisasi dan efektivitas komunikasi interpersonal terhadap kepuasan kerja secara gabungan adalah $37,6 \%$ sedangkan $62,4 \%$ dipengaruhi oleh faktor lain.

Berdasarkan perhitungan jalur di atas dapat disimpulkan pengaruh langsung dan tidak langsung iklim komunikasi organisasi (X), terhadap moralitas kepuasan kerja (Y2) melalui efektivitas komunikasi interpersonal (Y1) pada Tabel 11 di bawah ini.

Tabel 11 Nilai Koefisien Pengaruh Antar Variabel

\begin{tabular}{|l|l|l|l|}
\hline \multirow{2}{*}{ Pengaruh Variabel } & \multicolumn{3}{l|}{ Koefisien Pengaruh } \\
\cline { 2 - 4 } & Langsung & Tidak langsung & Total \\
\hline X terhadap Y1 & .290 & - & .290 \\
\hline Y1 terhadap Y2 & .541 & - & .541 \\
\hline X terhadap Y2 & .317 & .171 & .488 \\
\hline
\end{tabular}

(Sumber: Olahan peneliti, 2014)

Berdasarkan hasil pengujian pada tabel 9 dapat diketahui bahwa ada pengaruh positif dan signifikan antara iklim komunikasi organisasi dan efektivitas komunikasi interpersonal terhadap kepuasan kerja. Hasil pengujian ini memperlihatkan adanya pengaruh tidak langsung iklim komunikasi organisasi terhadap kepuasan kerja melalui efektivitas komunikasi interpersonal. Sehingga dapat disimpulkan bahwa ada pengaruh tidak langsung iklim komunikasi organisasi terhadap kepuasan kerja melalui efektivitas komunikasi interpersonal adalah sebesar 0.171 atau $17,1 \%$. Pernyataan ini sesuai dengan penelitian dari [27] yang berjudul pengaruh iklim komunikasi organisasi terhadap produktivitas kerja karyawan, yang menyatakan terdapat hubungan yang fungsional dan linear iklim komunikasi organisasi terhadap produktivitas kerja karyawan, diamping itu beliau juga menyatakan untuk dapat meningkatkan produktivitas kerja karyawan suatu perusahaan perlu memperhatikan iklim komunikasi organisasi. Perbedaan dengan penelitian ini dengan penelitian Pangumpia adalah pada jenis analis data, pangumpia menggunakan analisis data regresi sederhana sedangkan pada penelitian ini menggunakan analisis jalur.

Penelitian [17]menyatakan bahwa insentif, motivasi kerja, gaya kepemimpinan dan budaya organisasi baik secara parsial atau simultan berpengaruh terhadap kepuasan kerja personil polri pada Satuan Kerja Biro Operasi Polda Aceh. Berikutnya penelitian [18] menyatakan motivasi dan budaya organisasi berpengaruh positif terhadap kepuasan kerja karyawan PT. Pei Hai International Wiratama Indonesia. Selanjutnya [19] hasil penelitiannya di British International School menyatakan hubungan konpensasi yang diterima karyawan dan iklim organisasi secara bersama-sama menunjukkan hubungan yang sangat kuat dan positif terhadap kepuasan kerja. Namun hubungan konpensasi terhadap kepuasan kerja lebih besar dibandingkan hubungan iklim organisasi terhadap kepuasan kerja. Hal ini menunjukkan bahwa menciptakan konpensasi dan proses balas jasa yang baik terhadap karyawan akan lebih mendorong kepuasan kerja karyawan dibandingkan dengan mepnciptakan iklim organisasi yang baik.

Berdasarkan hasil uji analisis pengaruh langsung dan pengaruh tidak langsung iklim komunikasi organisasi terhadap kepuasan kerja di 
Dinas Kebudayaan, Pariwisata, Pemuda dan Olah Raga Kabupaten Gunung Mas Kalimantan Tengah menunjukkan hasil bahwa pengaruh tidak langsung iklim komunikasi organisasi menunjukkan hasil signifikaansi lebih tinggi daripada pengaruh langsung iklim komunikasi organisasi terhadap kepuasan kerja yaitu dengan nilai signifikansi untuk pengaruh tidak langsung adalah 0,000 dan signifikansi pengaruh tidak langsung adalah 0,036. Pengaruh tidak langsung iklim komunikasi organisasi terhadap kepuasan kerja tersebut dipengaruhi oleh efektivitas komunikasi interpersonal sebesar 17,1\% di Dinas Kebudayaan, Pariwisata, Pemuda dan Olah Raga Kabupaten Gunung Mas Kalimantan Tengah. Sikap mendukung pada komunikasi interpersonal merupakan faktor dominan pegawai. Hal ini menyatakan bahwa sikap mendukung pada Dinas Kebudayaan, Pariwisata, Pemuda dan Olah Raga Kabupaten Gunung Mas Kalimantan Tengah dapat terlaksana dengan baik guna untuk memberi dorongan kepada pegawai dalam meningkatkan kinerjanya, yakni berupa komunikasi yang terbuka dan empatik tidak dapat berlangsung dalam suasana yang tidak mendukung, sehingga kepuasan kerja akan ikut meningkat.

\section{KESIMPULAN}

Iklim komunikasi organisasi dipersepsikan oleh pegawai Dinas Kebudayaan, Pariwisata, Pemuda dan Olah Raga Kabupaten Gunung Mas Kalimantan Tengah memiliki pengaruh yang positif dan signifikan dengan kepuasan kerja. Pengaruh yang signifikan tersebut mempunyai makna semakin baik iklim komunikasi organisasi maka akan semakin baik pula kepuasan kerja pegawainya, sebaliknya semakin rendah iklim komunikasi organisasi maka semakin rendah kepuasan kerja pegawai.

Iklim komunikasi organisasi dipersepsikan oleh pegawai Dinas Kebudayaan, Pariwisata, Pemuda dan Olah Raga Kabupaten Gunung Mas Kalimantan Tengah memiliki pengaruh yang positif dan signifikan dengan efektivitas komunikasi interpersonal. Pengaruh yang signifikan tersebut mempunyai makna semakin baik iklim komunikasi organisasi maka akan semakin baik pula komunikasi interpersonal pada pegawai, sebaliknya semakin rendah iklim komunikasi organisasi maka semakin rendah komunikasi interpersonal pegawai.

Efektivitas komunikasi interpersonal dipersepsikan pegawai Dinas Kebudayaan, Pariwisata, Pemuda dan Olah Raga Kabupaten Gunung Mas Kalimantan Tengah memiliki pengaruh yang positif dan signifikan dengan kepuasan kerja. Pengaruh yang signifikan tersebut mempunyai makna semakin baik efektivitas komunikasi interpersonal maka akan semakin baik pula kepuasan kerja pegawainya, sebaliknya semakin rendah efektivitas komunikasi interpersonal maka semakin rendah kepuasan kerja pegawai.
Iklim komunikasi organisasi dipersepsikan pegawai Dinas Kebudayaan, Pariwisata, Pemuda dan Olah Raga Kabupaten Gunung Mas Kalimantan Tengah memiliki pengaruh yang positif dan signifikan dengan kepuasan kerja secara tidak langsung, melainkan melalui efektivitsa komunikasi interpersonal. Pengaruh yang signifikan tersebut mempunyai makna semakin baik efektivitas komunikasi interpersonal maka akan semakin baik pula iklim komunikasi organisasi berpengaruh terhadap kepuasan kerja pegawainya, sebaliknya semakin rendah efektivitas komunikasi interpersonal maka semakin rendah pengaruh iklim komunikasi organisasi terhadap kepuasan kerja pegawai. Sehingga iklim komunikasi di Dinas Kebudayaan, Pariwisata, Pemuda dan Olah Raga Kabupaten Gunung Mas Kalimantan Tengah akan ditingkatkan supaya komunikasi interpersonal semakin terjaga dengan baik dan kepusan kerja pegawai akan meningkat. Hal ini menunjukkan bahwa menciptakan efektivitas komunikasi interpersonal yang baik maka iklim komunikasi organisasi akan lebih mendorong kepuasan kerja pegawai.

\section{SARAN}

Hasil penelitian ini dapat mendorong dan memicu dilakukannya penelitian-penelitian berikutnya di bidang komunikasi dan organisasi dengan menggunakan variabel-variabel lain yang berbeda dengan penelitian ini seperti beberapa penelitian sebelumnya sehingga dapat diketahui faktor-faktor apa saja yang dapat mempengaruhi kepuasan kerja dalam organisasi.

Penelitian ini diharapkan dapat menambah wawasan serta informasi kepada lembaga untuk mengetahui pengaruh iklim komunikasi organisasi terhadap efektivitas komunikasi interpersonal dan kepuasan kerja di Dinas Kebudayaan, Pariwisata, Pemuda dan Olah Raga Kabupaten Gunung Mas Kalimantan Tengah agar dapat mengembangkan iklim komunikasi yang baik supaya tercapai kepuasan kerja yang diinginkan.

Hasil penelitian ini mampu memberikan masukan atau bahan evaluasi bagi Dinas Pariwisata, Pemuda dan Olah Raga Kabupaten Gunung Mas Kalimantan Tengah sebagai acuan dalam menerapkan iklim komunikasi organisasi yang baik sehingga terbentuknya efektivitas komunikasi interpersonal dan kepuasan kerja yang baik. Bahwa iklim komunikasi organisasi nilai terendah berada pada pernyataan Indikator "Perhatian pada tujuan kinerja yang tinggii", sehingga perlu perhatian seluruh anggota pegawai dalam mendukung pekerjaannya, yang dirasa agak rendah belum begitu memuaskan, belumlah sesuai seperti yang diharapkan oleh pegawai, agar iklim komunikasi organisasi di Dinas Pariwisata, Pemuda dan Olah Raga menjadi lebih baik. Pada efektivitas komunikasi interpersonal untuk skor yang paling rendah berada pada Indikator "sikap positif", yang merupakan kebutuhan pegawai dalam mendukung 
pekerjaannya, yang dirasa agak rendah belum begitu memuaskan, belumlah sesuai seperti yang diharapkan oleh pegawai. Sehingga perlu ditinggkatkan kepercayaan diri pada setiap pegawai supaya pegawai yang merasa negatif terhadap diri sendiri tidak selalu mengkomunikasikan perasaan ini kepada orang lain, yang selanjutnya barangkali akan mengembangkan perasaan negatif yang sama kepada pegawai lain.

Pada kepuasan kerja, untuk skor yang paling rendah berada pada pernyataan Indikator "kepuasan terhadap pengawasan", yaitu pegawai merasa kurang nyaman jika atasan atau rekan kerja yang lain mengawai kinerja dalam mendukung pekerjaannya, diharapkan pengawasan pada Dinas Dinas Pariwisata, Pemuda dan Olah Raga sesuai seperti yang diharapkan oleh pegawai sehingga kinerja pegawai bisa lebih baik lagi.

\section{UCAPAN TERIMA KASIH}

Segala puji syukur kepada Tuhan Yesus Kristus, atas limpahan Kasih Karunia-Nya. Terimakasih peneliti sampaikan kepada orang tua, saudara dan orang-orang tersayang. Selain itu terimakasih untuk dosen pembimbing Bapak Prof. Dr. Ir. Sanggar Kanto, M.S dan Bapak Rachmat Kriyantono, Ph.D, serta segenap keluarga besar Fakultas IImu Sosial dan IImu Politik Universitas Brawijaya Malang.

\section{DAFTAR PUSATAKA}

[1]. Muhammad, Arni. (2005). Komunikasi Organisasi. Jakarta: Bumi Aksara.

[2]. Handoko, T, H. (2003). Manajemen, Edisi kedua. Yogyakarta: BPFE.

[3]. Pace, R Wayne \& Faules Don F. (2006). Komunikasi Organisasi (Terjemahan Deddy Mulyana). Bandung: PT. Remaja Rosdakarya.

[4]. Littlejohn, Stephen W \& Foss A, Karen. (2011). Teori Komunikasi (Theories on Human Communication),edisi 9. Jakarta: Salemba Humanika.

[5]. Goldhaber, Gerald M. (1995). Organizational Communication: 6th edition. Dubuque, United States of America: Wm C. Brown Communication, Inc.

[6]. Rasberry, Robert W \& Lemoine, Laura F. (1986). Effective Managerial Communication, Kent Publishing Co, Boston.

[7]. Luthans, F. (1998). Organisational Behaviour. 8th ed. Boston: Irwin McGraw-Hill.

[8]. Kriyantono, Rachmat. (2010). Teknik Praktis Riset Komunikasi.Jakarta: Kencana Prenada Media Group.

[9]. Wood, T, Julia. (2013). Komunikasi Interpersonal Interaksi Keseharian Edisi 6. Jakarta: Salemba Humanika

[10]. Devito, Joseph A. (2011). Komunikasi antar manusia (edisi kelima). Jakarta: Proffesional Books.
[11]. Cahyono, Suharto, 2005, "Pengaruh Budaya Organisasi, Kepemimpinan Dan Motivasi Kerja Terhadap Kinerja Sumberdaya Manusia Di Sekretariat DPRD Propinsi Jawa Tengah, JRBI, Vol.1.

[12]. Lodge B. \& C. Derek, (1993), Organizational Behavior and Design. Terjemahan Sularno Tjiptowardoyo, Gramedia, Jakarta.

[13]. Gibson, Ivanevich dan Donnelly. (1995). Organisasi: Perilaku, Struktur, Proses. Edisi kelima, Jilid 1, Cetakan 8. Jakarta: Penerbit Erlangga.

[14]. Waridin \& Marshuki. (2006). Pengaruh Motivasi Kerja, Kepuasan Kerja, Budaya Organisai, dan Kepemimpinan Terhadap Kinerja Pegawai. Ekobis, Vol.7, No.2.

[15]. Robbins, Stephen P. (2001). Perilaku Organisasi. Pearson Education Asia. Pte. Ltd.

[16]. Mas'ud, F. (2004). Survei Diagnosis Organisasional, (konsep dan Aplikasi). Semarang: Badan Penerbit Universitas Diponegoro.

[17]. Nafrizal., Lubis R \& Idris S. (2012). Pengaruh Insentif, Motovasi Kerja, Gaya Kepemimpinan dan Budaya Organisasi Terhadap Kupasan Kerja serta dampaknya pada Kinerja Personil POLRI pada Satuan Kerja Biro Operasi Mapolda Aceh. Jurnal Manajemen.ISSN 2302-0199. Pp. 52-67.

[18]. Brahmasari, A, I \& Suprayetno A. (2008). Pengaruh Motivasi Kerja, Kepemimpinan dan Budaya Organisasi Terhadap Kepuasan Kerja Karyawan serta Dampaknya pada Kinerja Perusahaan. Jurnal Manajemen.ISSN 2302-0199. Pp. 52-67.

[19]. Sari, Elviera. (2009). Pengaruh Kompensasi dan Iklim Organisasi terhadap Kepusan Kerja. Jurnal Ilmu Administrasi dan Organisai. ISSN 08543844. Vol 16. No. 1.

[20]. Sugiyono. (2011). Metode Penelitian Kuantitatif Kualitatif dan R\&D. Bandung: Alfabeta.

[21]. Martini. (2003). Hubungan Antara Motivasi Berprestasi, Iklim Organisasi dan Komitmen Organisasi. Jakarta.

[22]. Bacal, Robert. (1999). Perpormance Managemant. New York: The McGraw-Hill Company, Inc.

[23]. Hariyanto, V. H. (1997). Crowding sebagai sumber stressor: afther effect-nya terhadap kinerja. Jurnal Amina, 49, 58-65.

[24]. Goldhaber, Gerald M. (1990). Organizational Communication, United States of America: Wm C. Brown Publisher, Inc.

[25]. Falcione, Raymond L. (1987). Communication Climate in Organization in Handbook of Organizational Communication: An Interdiciplinary Perspective. Newbury Park: Sage.

[26]. Pace, R Wayne \& Faules, Don F. (2001). Komunikasi Organisasi: Strategi Meningkatkan Kinerja Perusahaan. (Terjemahan Deddy 
Mulyana). Penerbit PT Remaja Rosdakarya Bandung.

[27]. Pangumpia, F. (2013). Pengaruh Iklim Komunikasi Organisasi Terhadap Produktivitas Kerja Karyawan di Bank Prisma Dana Manado. Journal "Acta Diurna". Vol.II?No.2/2013.

[28]. Aw, Suranto. (2011). Komunikasi Interpersonal. Yogyakarta: Graha Ilmu.

[29]. Hardjana, A.M. (2003). Komunikasi Intrapersonal \& Interpersonal. Jakarta: Kanisius.

[30]. Kurniawan, Sigit. (2012). Pengaruh Efektivitas Komunikasi Interpersonal terhadap Kinerja Karyawan pada Dinas Kebudayaan dan PAriwisata Provinsi Riau. Jurnal Ilmu Komunikasi Fakultas IImu Sosial dan IImu Politik Universitas Bina Widya. Riau.

[31]. Islami, Linda. (2011). Efektivitas Komunikasi Interpersonal dengan Tingkat Kepuasan Kinerja Karyawan. Jurnal Universitas Budi Luhur Jakarta. 